\title{
Ratkaisuja härkäpavun kasvinsuojeluun
}

\author{
Erja Huusela-Veistola, Heikki Jalli, Marja Jalli
}

MTT Kasvintuotannon tutkimus, 31600 Jokioinen, etunimi.sukunimi@mtt.fi

\section{Tiivistelmä}

Kiinnostus härkäpavun viljelyyn on kasvanut nopeasti viime vuosina. Härkäpavun viljelyala on nykyisellään n. 10000 ha. Samanaikaisesti viljelyn yleistymisen myötä on tutkittu härkäpavun kasvintuhoojien runsautta ja hallintakeinoja MTT:ssä käynnissä olevassa MoniPalko-hankkeessa etsitään ratkaisuja palkokasvien viljelyvarmuuden parantamiseen. Härkäpavun kasvintuhoojien hallinta on oleellinen osa viljelyvarmuutta.

Härkäpavun kanssa samaan aikaan taimettuvat rikkakasvit valtaavat alaa harvassa kasvustossa, joten niiden hallitsemiseksi tarvitaan keinoja ja sopivia rikkakasvien torjunta-aineita. Kemiallisen rikkakasvien torjunnan ongelmana on härkäpavun herkkyys monille tehoaineille ja kasville sopivien tehoaineiden heikko teho rikkakasveihin. Tähänastiset Off label -hyväksynnät tuovat apua härkäpavun rikkakasvien säätelyyn, vaikka rikkakasvilajiston ollessa hankala voi herbisidien teho jäädä riittämättömäksi.

Suklaalaikku on härkäpavun tärkein kasvitauti. Härkäpavun tyviä vioittavat samat kasvintuhoojat kuin herneellä. Taudinaiheuttajia on useita ja ne säilyvät joko kasvinjätteessä tai siemenessä. Terveen kylvösiemenen käyttö varmistaa tasaisen kasvuston ja vähentää kasvitautiriskiä. Kasvitautien torjunnassa viljelykierto on avainasemassa. Härkäpapua suositellaan viljeltäväksi samalla lohkolla vain joka neljäs vuosi. Suomessa viljeltävien härkäpapulajikkeiden taudinkestävyys on heikko ja taudeille suotuisissa olosuhteissa suositellaan kemiallista torjuntaa. Suklaalaikun kasvustoruiskutuksiin ja kylvösiemenen peittaukseen on Suomessa hyväksytty useita fungisidivalmisteita, mutta kemiallinen torjunta vaatii vielä tarkennusta.

Pahoja tuhoeläinongelmia härkäpavulla ei ole toistaiseksi ollut, mutta niiden ilmaantumiseen on kuitenkin varauduttava viljelyn vakiinnuttaessa asemaansa. Periaatteessa ongelmia voivat kuitenkin aiheuttaa samat tuhoeläimet kuin herneellä, joskin hernekääriäisen merkitys on selvästi vähäisempi. Todennäköisempiä härkäpavun vikuuttajia ovat juovahernekärsäkäs, hernekirva ja papukirva. Niiden torjuntaan härkäpavulle hyväksyttyjä torjunta-aineita ei tällä hetkellä ole. Viljelyalan laajetessa myös apilalla tuhoja aiheuttanut varsiankeroinen voi tulla ongelmaksi, jolloin viljelykierron merkitys tuhoeläintenkin kannalta kasvaa.

Härkäpavun kasvintuhoojien runsaudessa voi olla paljon paikallista ja ajallista vaihtelua. Suomeen sovellettavissa olevia härkäpavun kasvintuhoojien ennustejärjestelmiä ei ole valmiina, mutta herneellä ja muilla palkokasveilla käytettyjä kasvinsuojelukeinoja voidaan pääosin hyödyntää myös härkäpavulla. Tällä hetkellä rikkakasvien ja suklaalaikun torjunta ovat tärkeimpiä härkäpapukasvuston kasvinsuojelutoimenpiteitä. Tuhoeläinten torjunta voi joinakin kasvukausina myös olla tarpeen, joskaan härkäpavulle hyväksyttyjä hyönteistorjunta-aineita ei tällä hetkellä ole. Kasvintuhoojien tarkkailu (tunnistus ja seuranta) ja kokemuksista oppiminen (kylvöajan, siemenmäärän, kasvinsuojelun ym. viljelyteknisten toimenpiteiden optimointi) ovat uuden kasvin viljelyn yleistyessä aina tarpeen, koska monesti kasvintuhoojaongelmat lisääntyvät viljelyn laajetessa.

\section{Asiasanat}

Härkäpapu, valkuaiskasvit, palkokasvit, kasvinsuojelu, kasvitaudit, rikkakasvit, tuhoeläimet, suklaalaikku, tyvitaudit, fungisidit, herbisidit 


\section{Johdanto}

Härkäpapu, Vicia faba, on maailmalla yleisesti viljelty palkokasvi. Muiden palkokasvien tapaan härkäpapu on hyvä välikasvi viljapainotteiseen viljelykiertoon. Suomessa kiinnostus härkäpavun viljelyyn on kasvanut nopeasti viime vuosina, kun rehuteollisuus on alkanut kiinnostua härkäpavusta kotimaisena valkuaisenlähteenä. Härkäpavun viljelyala on nykyisellään n. 10000 ha. Kokemusta härkäpavun viljelystä ja kasvinsuojeluongelmista on vasta vähän eikä härkäpavun viljelyvarmuutta Suomessa ole juurikaan tutkittu. Viljelyn laajeneminen ja olosuhteiden vaihtelu on huomioitava etsittäessä sopivia keinoja härkäpavun kasvintuhoojien ja rikkakasvien hallintaan.

Moniruokaisille tai -isäntäisille kasvintuhoojille riittää peltoympäristössä sopivia isäntäkasveja, niin viljely- kuin rikkakasveja. Tiettyyn kasvilajiin erikoistuneiden kasvinsyöjien ja kasvitautien runsastuminen on kuitenkin riippuvainen isäntäkasvin alueellisesta ja ajallisesta esiintymisjakaumasta sekä sääolosuhteista. Monesti kasvintuhoojaongelmat lisääntyvät yksittäisen viljelykasvin viljelyn laajetessa (Altieri \& Letourneau 1982). Viljelykasvin viljelyalan kasvun seurauksena Suomessa runsastuneita ongelmallisia kasvintuhoojia ovat $\mathrm{mm}$. rapsikuoriainen Melighethes aeneus kevätöljykasveilla, kuminakoi Depressaria daucella kuminalla ja verkkolaikku Pyrenophora teres ohralla (Jalli et al. 2011). Kasvintuhoojat saavat helpommin jalansijaa, kun isäntäkasvin viljelyala ja -frekvenssi kasvavat. Esimerkiksi hernekääriäisongelmien todennäköisyys (Huusela-Veistola \& Jauhiainen 2006) ja herneen lehtilaikkutautien runsaus (Davidson \& Ramsay 2000) ovat sidoksissa herneen viljelyn laajuuteen. Samantyyppinen kasvinsuojeluongelmien runsastuminen voi olla mahdollista myös härkäpavun viljelyn yleistyessä.

Peltolohkon rikkakasvilajistossa ei tapahdu nopeita muutoksia. Rikkakasvien määrään ja lajistoon vaikuttavat viljelykierto ja viljelymenetelmät käytettyjä herbisidejä enemmän (Krähmer 2011). Härkäpapu on palkokasvi, joka ei tarvitse kasvaakseen paljoa lannoitetyppeä. Huolimatta pienestä typpilannoituksesta härkäpapu kasvaa rehevästi, mutta ei ole erinomainen kilpailija rikkakasveja vastaan (Abbes et al. 2007, Grenz et al. 2005). Härkäpavun rikkakasvien torjunta on tärkeä tekijä härkäpavun satopotentiaalin hyödyntämisessä ja sadon laadun turvaamisessa.

Härkäpavulla esiintyy pääosin samoja kasvintuhoojia ja kasvinsuojeluongelmia kuin herneellä ja muilla palkokasveilla. Erityisongelmiakin kuitenkin on, kuten suklaalaikku (Botrytis fabae, Botrytis cinerea) joka on härkäpavun yleinen kasvitauti. MTT:ssä käynnissä olevassa MoniPalko-hankkeessa etsitään ratkaisuja palkokasvien viljelyvarmuuden parantamiseen. Härkäpavun kasvintuhoojien hallinta on oleellinen osa viljelyvarmuutta.

\section{Härkäpavun rikkakasvien torjunta}

Härkäpavun rikkakasvien hallitsemiseksi tarvitaan uusia keinoja ja sopivia rikkakasvien torjuntaaineita. Kemiallisen rikkakasvien torjunnan ongelmana on härkäpavun herkkyys monille tehoaineille (Betts \& Morrison 1979, Garcia de Arevalo 1992) ja kasville sopivien tehoaineiden heikko teho rikkakasveihin.

Härkäpavun viljelyn laajentuessa Suomessa rikkakasvien torjumiseksi oli käytettävissä herneelläkin käytetty bentatsoni-tehoaine (Basagran SG -valmiste). Sillä ei saada tehoa linnunkaaliin, orvokkiin, peippeihin, piha- ja kiertotattareen eikä pillikkeisiin, eikä teho ole aina riittävä emäkkiin, lemmikkiin, jauhosavikkaan tai ukontattareen. Ennen härkäpavun taimettumista käytettävän metatsaklorin (Butisan S) teho ei paljon poikkea bentatsonista, paitsi mataratehon suhteen. Rikkakasvien hallitsemiseksi tarvitaan uusia keinoja ja sopivia rikkakasvien torjunta-aineita.

Monipalko-hankkeessa tutkittiin herneelle hyväksyttyjen valmisteiden sopivuutta härkäpavun rikkakasvien torjuntaan kahdella koepaikalla (Jokioisilla ja Koskella Tl) vuosina 2009-2010 (Jalli 2012). Testatut valmisteet olivat pääosin herneen ja pavun rikkakasvien torjuntaan hyväksyttyjä valmisteita. Vuonna 2009 koejäseninä olivat Afalon-neste (linuroni) 1,5 ja 2,0 1/ha sekä Fenix (aklonifeeni) 2,0 ja 2,5 1/ha ennen härkäpavun taimettumista, Basagran SG (bentatsoni) 1,7 kg/ha ja Senkor (metributsiini) 0,4 kg/ha härkäpavun ollessa 2-4 lehtiasteella ja Fenix (aklonifeeni) 3,0 1/ha, kun härkäpapu oli 5-8 cm korkeaa. 
Kasvukaudella 2009 suurimman rikkakasvimassan kasvattivat peltoemäkki, peltomatara, pillike, jauhosavikka sekä kierto- ja pihatatar, ja rikkakasvien yhteismassa oli 420 kuiva-aine $\mathrm{kg} / \mathrm{ha}$. Härkäpavun taimettumisen jälkeen käytetty Senkor vioitti härkäpapua erittäin pahoin. Lisäksi Jokioisilla härkäpavun taimettumisen jälkeen käytetyt Afalon ja Fenix vioittivat kasvia, Kosken kentällä vain Fenix (Kuva 1.) Kesällä 2009 rikkakasveja torjuivat parhaiten Fenix-käsittelyt ennen härkäpavun taimettumista käytettynä, jättäen kiertotattaren. Herbisidikäsittelyjen vioitukset näkyivät myös härkäpavun painoissa.

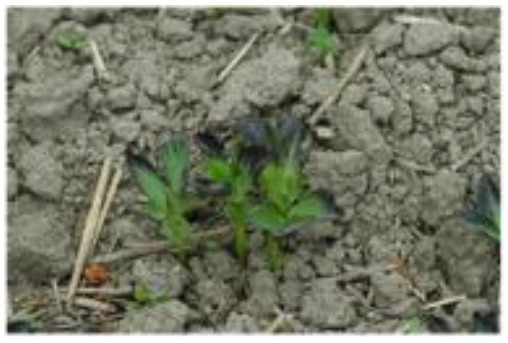

Senkor $0,4 \mathrm{~kg} /$ ha taimettumisen jälkeen käytettynä

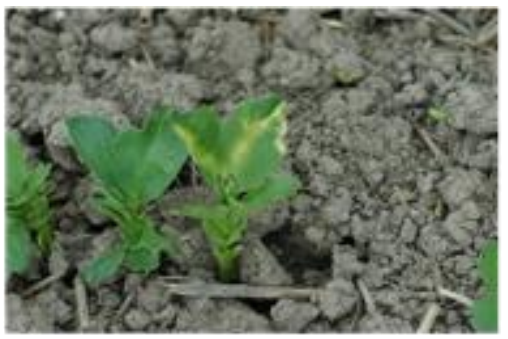

Fenix 3,0 I/ha taimettumisen jälkeen käytettynä

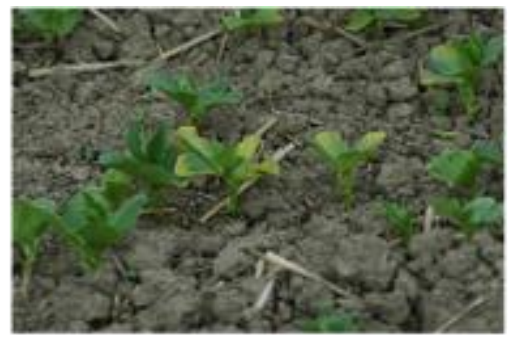

Afalon $2.0 \mathrm{l} /$ ha ennen taimettumista käytettynä

Kuva 1. Rikkakasvitorjunnan aiheuttamia vioituksia härkäpavun taimissa kesällä 2009. (Kuvat Heikki Jalli)

Kesän 2010 oloissa suurimman massan kasvattivat pillike, punapeippi, jauhosavikka ja kiertotatar, ja rikkakasvien yhteismassa oli 135 kuiva-aine kg/ha. Kokeissa ei ollut mukana Senkoria eikä Afalonia. Uusina koejäseniä oli Boxer (prosulfokarbi) 4,0 l/ha, Gallery (isoksabeeni) 0,25 1/ha ja Centium (klomatsoni) 0,20 1/ha, joiden käsittelyt tehtiin ennen taimettumista. Kesällä 2010 herbisideistä johtuvat vioitukset jäivät vähäisemmiksi kuin edellisenä vuonna, vain taimettumisen jälkeen ruiskutettu Fenix vioitti härkäpavun taimia. Parhaimmat rikkakasvien torjuntatulokset saatiin ennen härkäpavun taimettumista tehdyillä Fenix -käsittelyillä, jotka eivät torjuneet riittävästi pillikettä ja kiertotatarta. Myös Basagranilla ja Boxerilla saatiin hyvä teho rikkakasvien massaan (teho yli $80 \%$ ) Basagan ei torjunut pillikettä eikä Boxer jauhosavikkaa. Torjuntateho ei ollut riittävä Centiumilla, Galleryllä, Goltixilla. Goltix tehosi pillikkeeseen , mutta muuten teho oli kaikilla heikko pillikkeeseen, kiertotattareen, jauhosavikkaan ja punapeippiin. Myös taimettumisen jälkeen käytetyn Fenixin teho rikkakasvimassoihin oli 50 prosentin luokkaa.

Härkäpavun leveälehtisten rikkakasvin torjuntaan sallittuja rikkakasvien torjunta-aineita ovat Basagran SG (bentatsoni), Butisan S (metatsaklori) ja Fenix (aklonifeeni). Ennen härkäpavun taimettumista käytettävä Fenix sopii härkäpavun rikkakasvien torjuntaan, mutta ei viljelykasvin taimille ruiskutettuna. Fenix sai huhtikuussa 2010 Off label -hyväksynnän härkäpavun rikkakasvien torjuntaan ennen härkäpavun taimettumista. Aklonifeeni, bentatsoni tai metatsaklori eivät kuitenkaan torju linnunkaalia, orvokkia, pihatatarta ja pillikkeitä, eikä teho ole riittävä emäkkiin eikä kiertotattareen. Juolavehnän ja hukkakauran torjuminen härkäpapukasvustosta tuli mahdolliseksi, kun Agil 100 EC sai huhtikuussa 2010 Off label -hyväksynnän. Tähänastiset Off label -hyväksynnät tuovat apua härkäpavun rikkakasvien torjuntaan, vaikka rikkakasvilajiston koostuessa pillikkeestä tai kiertotattaresta voi herbisidien teho jäädä riittämättömäksi.

\section{Härkäpavun kasvitaudit ja niiden hallinta}

Sadon suuret vaihtelut rajoittavat kiinnostusta härkäpavun viljelyn laajenemiseen. Kasvin alttius kasvintuhoojia vastaan selittää osaltaan odotettua pienemmät sadot. Lukuisat maa-, kasvijäte-, ja ilmalevintäiset taudinaiheuttajat voivat aiheuttaa vakavia kasvitautiongelmia härkäpapukasvustossa (Stoddard et al. 2010). Kasvitaudeista härkäpavun viljelyä Suomessa rajoittaa merkittävimmin suklaalaikku, jota aiheuttavat sienet Botrytis fabae Sard. ja Botrytis cinerea Pers. ex Fr (Kuva 2). Suklaalaikun aiheuttajien lisäksi on Suomen härkäpapupelloilta eristetty 28 sadon muodostukseen vaikuttavaa sientä. Näistä taudinaiheuttajina merkittävimmät ovat Fusarium spp. sekä Ascochyta fabae 
Speg. (Roukola \& Vestberg 1978). Kosteana ja lämpimänä kasvukautena 2011 härkäpapukasvustoissa esiintyi paikoin runsaasti myös ruostetta (Uromyces viciae-fabae Pers.) (Kuva 2). Sääolosuhteet ovat suurin eri taudinaiheuttajien esiintymiseen vaikuttava tekijä (Roukola \& Vestberg 1978).
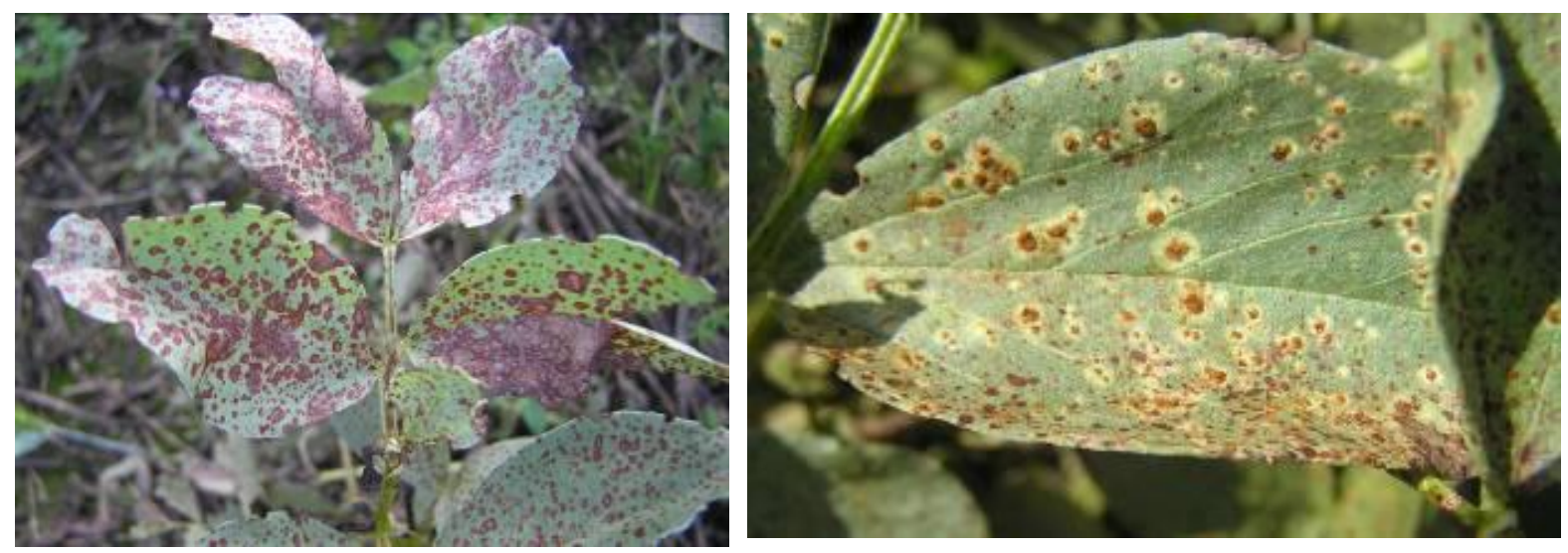

Kuva 2. Suklaalaikku aiheuttaa kasvin maanpäällisiin osiin 1-3 mm:n kokoisia, punertavan ruskeita selvärajaisia laikkuja (vasen). Härkäpavun ruosteen alkuoireet näkyvät pieninä vaaleanvihreinä laikkuina, joista myöhemmin pursuaa punertavan ruskeaa itiömassaa (oikea). (Kuvat Marja Jalli)

Kasvitautien tunnistaminen, niiden seuranta kasvukauden aikana ja eri torjuntakeinojen monipuolinen käyttö tukevat härkäpavun viljelyn onnistumista. Huolellisella viljelytekniikalla voidaan estää kasvintuhoojien lisääntymistä (Stoddard et al. 2010). Härkäpapua suositellaan viljeltäväksi samalla lohkolla vain joka neljäs vuosi. Tartuntariski pienenee, jos edellisen vuoden lohkoihin on vähintään 500 m:n etäisyys. Rikkakasvien torjunta parantaa kasvuston ilmavuutta ja vähentää taudinaiheuttajille alttiiden isäntäkasvien määrää. Kylvösiemenen kuntoa edistävät kasvukauden onnistunut torjunta, siemensadon mahdollisimman aikainen korjuu sekä tarvittaessa kylvösiemenen peittaus. Lajikkeen taudinkestävyys on tehokas ja taloudellinen keino kasvitautien hallintaan. Useimpia härkäpavun taudinaiheuttajia vastaan on kuvattu monia taudinkestävyyslähteitä. Niiden tuloksellinen hyödyntäminen kasvinjalostuksessa edellyttää tehokkaita geenitekniikan menetelmiä, resistenssin geneettisen taustan sekä taudinaiheuttajien virulenssin tuntemista (Sillero et al. 2010). Suomessa viljeltävien härkäpapulajikkeiden taudinkestävyys on heikko ja taudeille suotuisissa olosuhteissa suositellaan kemiallista torjuntaa. Suklaalaikun torjuntaan on Suomessa hyväksytty Topsin M (tiofanaatti-metyyli), Switch 62.5 WG (syprodiniili ja fludioksoniili) sekä Amistar (atsoksistrobiini) valmisteet. Siemenlevintäisten tyvitautien torjuntaan on hyväksytty tiraami, iprodioni- ja sädesienivalmisteet.

Monipalko-hanke selvitti siemenen peittauksen ja kasvustoruiskutusten tehokkuutta härkäpavun yleisimpien kasvitautien hillitsijänä. Peittauksessa testattuja tehoaineita olivat: fludioksoniili, iprodioni, Pseudomonas chlororaphis MA 342, Streptomyces K61 ja tiraami. Kasvustoruiskutuksissa testattiin propikonatsolin, protiokonatsolin ja atsoksistrobiinin vaikutusta lehtiä vioittaviin taudinaiheuttajiin.

Kaikki testatut peittausaineet vähensivät voimakkaita härkäpavun tyvitautioireita. Vaikutus oli selvin, kun siemenerä oli pahoin taudinaiheuttajien tartuttama. Biologisella Pseudomonas chlororaphis MA 342-tehoaineella peitattu kasvusto iti käsittelemätöntä kasvustoa paremmin, mikä näkyi myös $15 \%$ parempana sadontuottona. Muilla valmisteilla tehokkuus taudinaiheuttajien torjuntaan ei heijastunut sadonmuodostukseen asti. Merkittävänä esteenä tähän oli peittausaineiden rakenne. Jotta jauhemaiset peittausaineet saatiin tarttumaan siemenen pinnalle, käytettiin apuna siemenen kastelua. Tämä aiheutti ongelmia kylvössä ja kasvustot jäivät paikoin aukkoisiksi. Millään peittauskäsittelyllä ei ollut vaikutusta kasvukauden aikaisten lehtilaikkutautien esiintymiseen.

Monipalko-hankkeen lohkoilla suklaalaikku eteni aggressiiviseen vaiheeseen asti vain kasvukautena 2011. Kasvukausina 2009-2010, jolloin tartuntatasot olivat alhaiset, torjunta ei vaikuttanut kasvuston kuntoon eikä sadonmuodostukseen. Heinäkuusta 2011 sadonkorjuuseen asti kosteusolosuhteet olivat taudin leviämiselle optimaaliset. Elokuun alussa suklaalaikku eteni muutamassa viikossa nopeasti ja syyskuun alussa kasvusto oli täysin laikkutautien tuhoama. 
Protiokonatsoli-valmisteella käsitellyt ruudut olivat muita ruutuja vihreämpiä (Kuva 3). Tautitorjunta vaikuttaa joko muodostuvien palkojen lukumäärään vähentämällä kukkainfektiota tai siemenen kokoon pitämällä lehdet pidempään yhteyttämiskykyisenä. Kokeissa vaikutus kohdistui siemenen täyttymiseen. Siemenen koko oli suurempi protiokonatsoli- ja atsoksistrobiini-valmisteilla käsitellyissä ruuduissa. Satovaikutukset jäivät silti vähäisiksi eikä merkittäviä eroja eri käsittelyjen välillä ollut. Kasvukauden aikaisen torjunnan tavoitteena on suojata sekä kehittyvät kukinnot että yhteyttävät lehdet. Koska härkäpavun kasvuaika on pitkä, on erityistä huomiota kiinnitettävä torjunnan ajoitukseen. Aikaisessa ja voimakkaassa tautipaineessa voi jaettu torjunta olla kannattavaa. Torjuntatarpeen arviointi ja torjunnan onnistuminen edellyttävät aktiivista kasvuston oireiden ja sääolojen seurantaa.

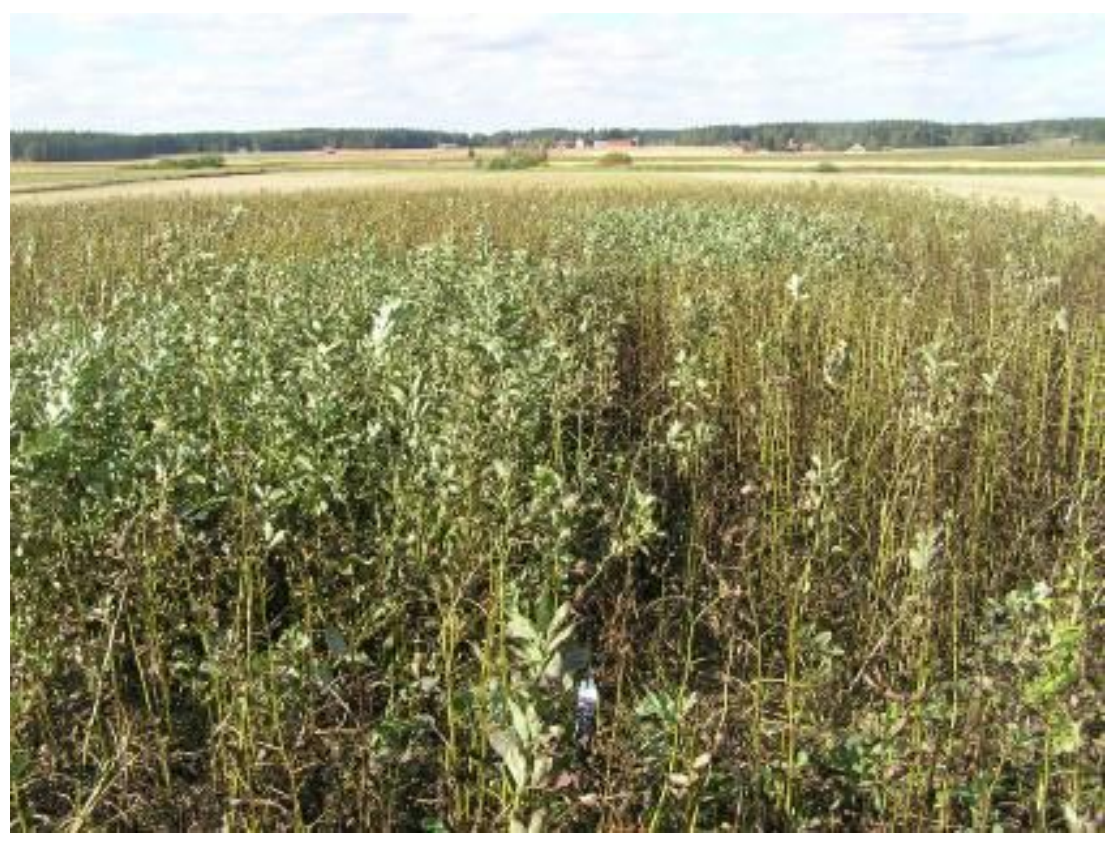

Kuva 3. Härkäpavun kasvitautien torjuntakokeessa protiokonatsoli-tehoaineella käsitellyt koeruudut erottuivat muita koeruutuja vihreämpinä. Jokioinen 2.9.2011. (Kuva Marja Jalli)

\section{Härkäpavun tuhoeläimet ja niiden hallinta}

Maailmanlaajuisesti härkäpavulla on havaittu yli 70 tuholaislajia, mutta lajisto vaihtelee paljon alueellisesti (Stoddard ym. 2010). Suomessa härkäpapua vioittavat samat tuhoeläimet kuin hernettäkin. Aikuiset juovahernekärsäkkäät Sitona lineatus vaurioittavat pieniä taimia nakertamalla lehtien reunaan koloja (Kuva 4). Kärsäkkään toukat vioittavat juurinystyröitä, mutta vioituksen merkitystä satoon ei tarkkaan tiedetä. Kärsäkäsongelmat ovat tavallisempia kuivina ja lämpiminä keväinä, mutta reheväkasvuinen härkäpapu toipuu yleensä hyvin vioituksista. Lämpiminä kesinä heinä-elokuussa kuoriutuvat uuden sukupolven aikuiset juovahernekärsäkkäät voivat vioittaa härkäpapukasvustojen latvustoja, mutta sillä ei liene juurikaan taloudellista merkitystä. Hernekirva Acyrthosiphon pisum on yleinen palkokasvien tuholainen, jota esiintyy myös härkäpavulla (Kuva 4). Lisäksi härkäpavun latvustossa viihtyy moni-isäntäinen papukirva Aphis fabae, jonka yli 200 isäntäkasvin joukkoon kuuluu myös monia rikkakasveja, kuten meillä yleiset jauhosavikka ja peltoohdake. Kirvat lisääntyvät parhaiten lämpimässä ja ovat runsaimmillaan yleensä heinäkuussa härkäpapukasvuston kukkiessa. Suoran imentävioituksen lisäksi kirvoista on haittaa myös epäsuorasti, koska ne voivat levittää useita kasvien virustauteja (Makkouk 1998). Vaikka hernekääriäisen Cydia nigricana vioitus härkäpavulla jää yleensä vähäiseksi, on härkäpavun kääriäistuhoja raportoitu esimerkiksi Puolassa (Niezgodzinski 1965). Kirjallisuudessa härkäpavun pahoina tuholaisina mainitaan myös varsiankeroinen Ditylenchus dipsaci ja siemeniä pahoin vioittava härkäpapupiilokas 
Bruchus rufimanus (Biddle \& Carrouee 1996). Varsiankeroinen oli aikoinaan ongelma apilanviljelyssä, mutta härkäpapupiilokas ei ole toistaiseksi vakiintunut Suomeen.
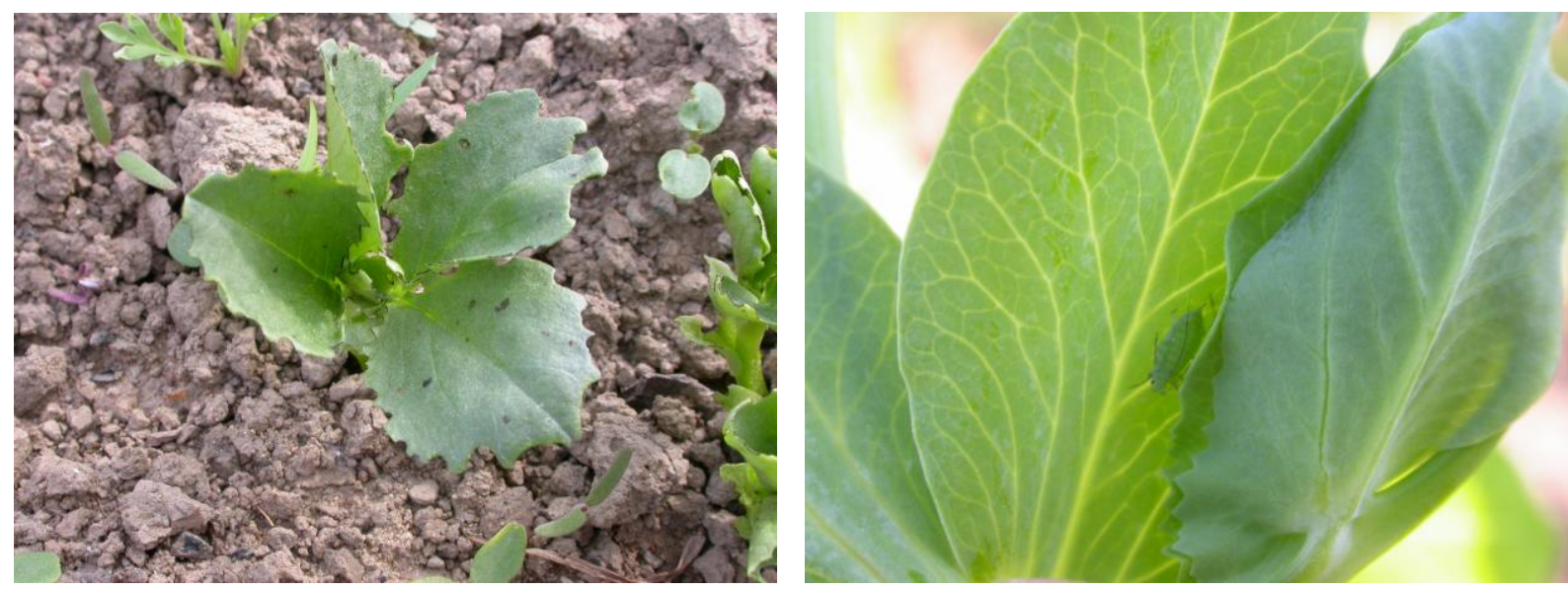

Kuva 5. Juovahernekärsäkkäät vioittavat härkäpavun taimia nakertamalla lehtien reunoja (vasen). Hernekirva vioittaa myös härkäpapua ja voi levittää kasviviruksia (oikea). (Kuvat Erja Huusela-Veistola)

MoniPalko-hankkeen härkäpapulohkoilla tuhoeläinten vioituksia esiintyi kohtuullisen vähän. Kenttäkokeet keskittyivät härkäpavun rikkakasvien ja suklaalaikun hallintaan, eikä tutkituilla koetekijöillä havaittu olevan vaikutusta tuhoeläinmääriin. Hernekärsäkkään vioitusta havaittiin härkäpavun taimissa kaikilla koelohkoilla. Hernekirvoja oli runsaasti Jokioisten härkäpapulohkoilla heinäkuussa 2010. Vuonna 2009 Jokioisten härkäpapukasvustosta löytyi yksittäisistä kasveista Megoura viciae -kirvaa, jonka isäntäkasveja ovat härkäpavun lisäksi mm. niittynätkelmä ja hiirenvirna. Härkäpapulohkoilla olleisiin hernekääriäisen feromoniansoihin tuli runsaasti aikuisia hernekääriäisiä, mutta vioituksia härkäpavun paloissa ei siitä huolimatta juurikaan havaittu.

Vaikka härkäpavulla ei viljelyn alkuvuosina ole havaittu pahoja tuhoeläinongelmia, on niiden ilmaantumiseen kuitenkin varauduttava viljelyn vakiinnuttaessa asemaansa. Monet palkokasvien tuhoeläimet ovat liikkuvia eikä pelkkä lohkokohtainen kasvinvuorotus niiden hallinnassa riitä. Härkäpavun ja viljan seosviljelyn on kuitenkin todettu vähentävän mm. kirvojen määrää härkäpavulla (Patriquin ym. 1988). Tuhoeläinten esiintyminen ja niiden aiheuttamat satotappiot ovat usein sattumanvaraisempia kuin kasvitautien eikä tuhoeläimille resistenttien lajikkeiden jalostukseen ole juurikaan panostettu. Kemiallinen torjunta pyretroideilla voisi olla tarpeen tuhoeläinten hallinnassa, jos hernekärsäkästä esiintyy erittäin runsaasi keväällä tai kukintavaiheessa kasvustoissa on reilusti kirvoja. Tällä hetkellä herneen tuhoeläinten torjuntaan käytettävillä pyretroideilla ei kuitenkaan ole virallista hyväksyntää härkäpavun tuhoeläinten torjuntaan.

\section{Johtopäätökset}

Härkäpavun kasvintuhoojien runsaudessa voi olla paljon paikallista ja ajallista vaihtelua. Suomeen sovellettavissa olevia härkäpavun kasvintuhoojien ennustejärjestelmiä ei ole valmiina, mutta herneellä ja muilla palkokasveilla käytettyjä kasvinsuojelukeinoja voidaan pääosin hyödyntää myös härkäpavulla. Tällä hetkellä rikkakasvien ja suklaalaikun torjunta ovat tärkeimpiä härkäpapukasvuston kasvinsuojelutoimenpiteitä. Terveen kylvösiemenen käyttö varmistaa tasaisen kasvuston ja vähentää kasvitautiriskiä. Lämpiminä kasvukausina on varauduttava myös härkäpavun ruosteen torjuntaan. Tuhoeläinten torjunta voi joinakin kasvukausina myös olla tarpeen, joskaan härkäpavulle hyväksyttyjä hyönteistorjunta-aineita ei tällä hetkellä ole. Kasvintuhoojien tarkkailu (tunnistus ja seuranta) sekä kokemuksista oppiminen (kylvöajan, siemenmäärän, kasvinsuojelun ym. viljelyteknisten toimenpiteiden optimointi) ovat uuden kasvin viljelyn laajetessa aina tarpeen. 


\section{Kirjallisuus}

Abbes, Z., Kharrt, M., Delavault,P., Simier, P \& Chaibi, E. 2007. Field evaluation of the resis-tance of some faba bean (Vicia faba L.) genotypes to the parasitic weed Orobanche foetida Poiret. Crop Protection 26:17771784.

Altieri, M.A. \& Letourneau, D.K. 1982. Vegetational management and biological control in agroecosystems. Crop Protection 1: 405-430.

Betts, M., F. \& Morrison I. N. 1979. Fall and spring applications of trifluralin and metribitzin in faba beans (Vicia faba). Weed Science 27: 61-64.

Biddle, A. \& Carrouee, B. 1996. Pests: a constraint for productivity of peas, faba beans and lupins. Grain Legumes 15: 12-13

Davidson, J.A. \& Ramsey, M.D. 2000. Pea yield decline syndrome in South Australia: the role of diseases and the impact of agronomic practices. Australian Journal of Agricultural Research 51: 347-354.

Garcia de Arevalo R. C., Sanchez, M. A., Algarra, P.J.H., Lusarreta, C. A. \& Veyra, C.B. 1992. Chemical control of annual weeds in field beans (Vicia faba) in central Spain. Weed science 40: 96-100.

Grenz, J. H., Manschadi, A. M., Uygur, F.N. \& Sauerborn, J. 2005. Effects of environment and sowing date on the competition between faba bean (Vicia faba) and the parasitic weed Orobanche crenata Field Crops Research 93: 300-313

Huusela-Veistola, E., \& Jauhiainen, L. 2006. Expansion of pea cropping increases the risk of pea moth (Cydia nigricana; Lep., Tortricidae) infestation. Journal of Applied Entomology, 130, 142-149.

Jalli, H. 2012. Härkäpavun uusien herbisidien testaus. Posteriesitys. Maataloustieteen päivät 2012 www.smts.fi Jalli, M., Laitinen, P., Latvala, S. 2011. The emergence of cereal fungal diseases and the incidence of leaf spot diseases in Finland. Agricultural and Food Science 20, 1: 62-73.

Krähmer H. 2011. Mapping of European Weeds Achievements of the EWRS - Working Group

3rd EU Weed Mapping Meeting, September 21-23, 2011 in Jokioinen http://www.ewrs.org/weedmapping/docs/ 2011_Jokioinen_presentations/2_Krahmer_EWRS_Weed_Mapping_Jokioinen_2011.pdf

Makkouk, K.M. 1998. Virus diseases of legume crops transmitted persistently by sucking insects. Grain Legumes 21: 9-10.

Niezgodzinski, P. 1965. Pea moth Laspeyresia nigricana Stepth. (Lepidoptera, Tortricidae) a new pest of broad bean in Poland. Polskie Pismo Entomologiczne Seria B Entomologia Stosowana 1/2: 177-179.

Patriquin, D.G., Baines, D., Lewis, J. \& MacDougall, A. 1988. Aphid infestation of faba beans on an organic farm in relation to weeds, intercrops and added nitrogen. Agriculture, Ecosystems and Environment 20: 279-288.

Roukola, A.-L.\& Vestberg, M. 1978. Fungus diseases of field bean in Finland during 1975-1977. Journal of the Scientific Agricultural Society of Finland 50: 455-467.

Sillero, J.C., Villegas-Fernández, A.M., Thomas, J., Rojas-Molina, M.M., Emeran, A.A., FernándezAparicio, M. \& Rubiales, D. Faba bean breeding for disease resistance. Field Crops Research 115: $297-307$.

Stoddard, F.L., Nicholas, A.H., Rubiales, D., Thomas, J. \& Villegas-Fernandez, A.M. 2010. Integrated pest management in faba bean. Field Crops Research 115: 308-318. 